\title{
THE EFFECT OF ACUTE GAMMA IRRADIATION OF THE HEAD ON THE ERYTHROPOIESIS IN VARIOUS REGIONS OF THE HEMOPOIETIC SYSTEM IN MICE
}

\author{
J. VÁCHA, M. POSPÍŠIL, JIŘINA HOLÁ and JAROMÍRA NETÍKOVÁ \\ Institute of Biophysics of the Czechoslovak Academy of Sciences, 61265 Brno
}

Received fuly 24, 1984

\begin{abstract}
Vácha J., M. Pospíšil, Jiřina Holá, Jaromira Netíková: The Effect of Acute Gamma Irradiation of the Head on the Erythropoiesis in Various Regions of the Hemopoietic System in Mice. Acta vet. Brno, 54, 1985: 189-205.

A decline of ${ }^{59} \mathrm{Fe}$ incorporation into the heme fraction of the bone marrow of the skull to roughly $70 \%$ of the physiological state took place in animals whose heads were irradiated with a dose of $16 \mathrm{~Gy}$ of ${ }^{60} \mathrm{Co}$-gamma radiation in the whole interval of 14-69 days post irradiation studied. A decline of ${ }^{59} \mathrm{Fe}$ incorporation to roughly $40 \%$ took place in the shielded (non-irradiated) bones on the 14th day, post irradiation; however, a recovery followed, reaching the initial values between the 30th and 40th days after irradiation. While the depth of the postirradiation decline is about the same in all the bone regions shielded, the acral bones showed - in contradistinction to the long ones - a marked overshoot above the control values (i. e., an indication of ectopic erythropoiesis) in the recovery phase. The main place of ectopic erythropoiesis was the spleen, however. The temporary decline of erythropoiesis in the shielded regions, accompanied by anemization of the animal, could be interpreted as a result of worsened nutritional conditions in the framework of the "oral postirradiation syndrome", compensated for by a wave of regenerating erythropoiesis with the involvement of ectopic localities after the recovery of nutrition.
\end{abstract}

Partial head irradiation, oral postirradiation syndrome, erythropoiesis in individual bones and spleen, heme iron.

In spite of its considerable practical importance, the question of the effects of irradiation of head region on hemopoietic functions had been studied only rarely. Irradiation of the head of laboratory rodents induces a complex of symptoms including effects on the oral cavity and central nervous system. Quastler et al. (1956) demonstrated the dependence of early mortality of mice on the extent of irradiated oral mucosa in the dose span of 14 to $40 \mathrm{~Gy}$. Goepp and Fitch $(1962,1963)$ proved that an important factor in the death of animals is starvation and dehydration. Damage to the mucosa of the posterior dorsum of the tongue and soft palate would appear to lead to a decrease in the intake of food and water after doses of 20 and $40 \mathrm{~Gy}$. An important role of the voral syndrome" in the pathogenesis of changes taking place after the head irradiation does not exclude, however, participation of other factors connected with the damage to the central nervous system (Yoshii et al. 1981).

In contradistinction to the organs localized in the skull just mentioned, irradiation of the head affects only a small part of the hemopoietic system. In C57BL/10ScSnPh mice, i. g., erythropoiesis in the skull (including the mandible) represents only $6.71 \pm 0.59 \%$ of the total marrow erythropoiesis (Vácha et al. 1982a). It is not surprising, therefore, that blood cell counts displayed no typical pattern after local head irradiation with doses in the range of $14-30 \mathrm{~Gy}$ in mice and rats and that the changes were not pronounced enough to explain the death of the animals (e. g., Quastler et al. 1956). Known facts on the important role of inanition and dehydration in the pathogenesis of the oral syndrome enables us to suppose that the local irradiation of head predominantly affects erythropoiesis. Fasting depresses the basal metabolism and damps the production of erythropoietin (Krantz and Jacobson 1970; Caro et al. 1981). In addition the decrease of 
water consupmption brings about relative polyglobulia, which suppresses erythropoiesis (Kilbridge et al. 1969), possibly by some other mechanism than decreased erythropoietin production (Dunn 1978). Archambeau et al. (1968) studied blood cell counts in mice fasting for five days and found a more pronounced depression of erythropoiesis in comparison with myelopoiesis. Abscopal effects were also, however, ascertained after local irradiation of one extremity, where erythropoiesis was depressed in the marrow of contralateral, shielded femurs (Wertz et al. 1977, 1978); analogical effects should obviously be taken into consideration with the local head irradiation, too.

We used our original method of the determination of the intensity of erythropoiesis (Vácha et al. 1978) to the study of the effects of total-head irradiation on the production of red blood cells in individual shielded parts of the erythropoietic system. No extensive attempt was made to elucidate experimentally the underlying pathogenetic mechanisms.

\section{Materials and Methods}

\section{Experimental Animals and Arrangement of Experiments}

Inbred male mice of the strain $\mathrm{C} 57 \mathrm{BL} / 10 \mathrm{ScSnPh}$ were used, two months old at the time of irradiation, with a mean body weight of $26 \mathrm{~g}$. Standard pelleted food and drinking water were provided ad libitum. The animals were kept in cages containing 20 individuals, ten of which were subjected to irradiation while the other ten formed the control group. Three types of experiments were performed on different groups of animals: studies of body weight and of peripheral blood parameters; study of circulating erythrocyte mass volume; studies of ${ }^{59} \mathrm{Fe}$ incorporation into the hemopoietic tissues and of changes in splenic weight. All experimental animals were irradiated at the same time of year in order to take into account any seasonal fluctuations which may occur in the functions studied. Control values were always recorded in parallel.

\section{Irradiation}

For irradiation of the head a gamma source of ${ }^{60} \mathrm{Co}$ (Chisostat, Chirana) was used. Irradiation of the head was made possible by a specially constructed chamber consisting of ten radially arranged segments for the fixation of the head in the field of irradiation and shielding of the rest of the body.

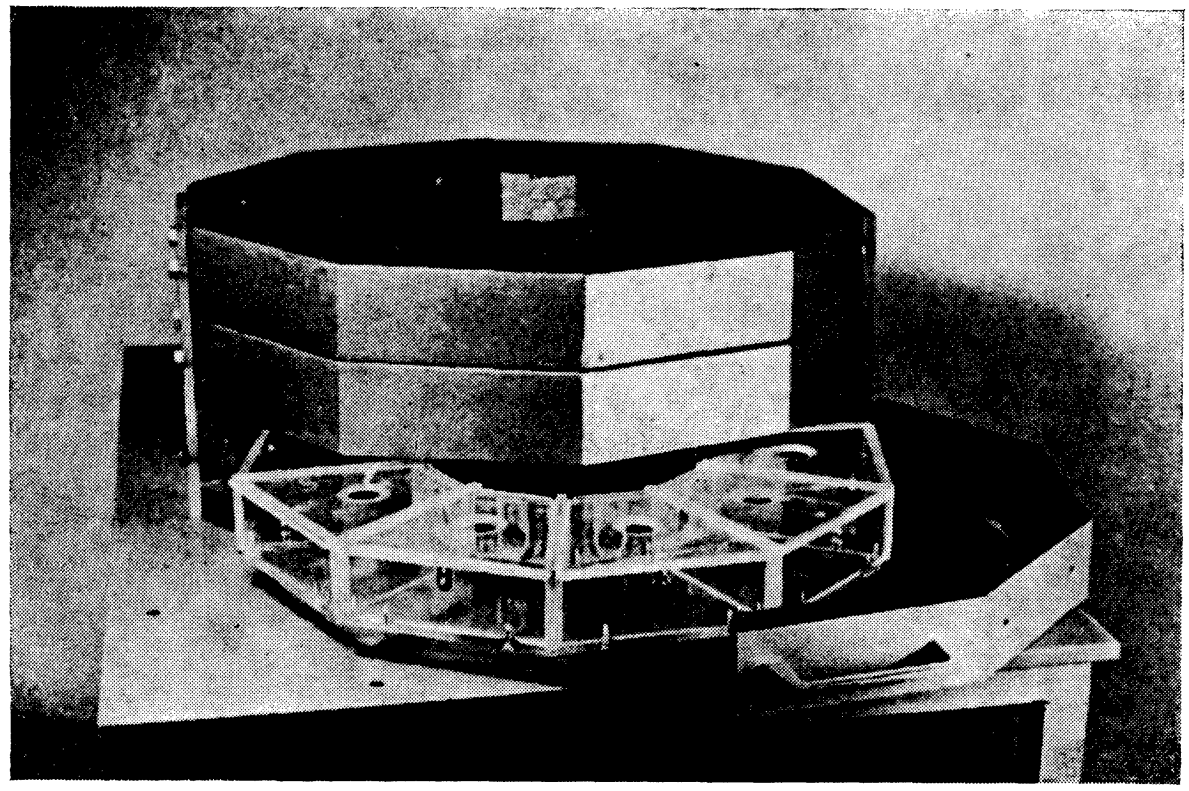

Fig. 1

General view of the specially constructed irradiation chamber enabling irradiation of the head of the animal with the rest of the body shielded. 
The shielding above the segments consisted of a $10 \mathrm{~cm}$ thick layer of lead; the internal $(0.5 \mathrm{~cm})$ walls of the segments and also the external and bottom shield $(2 \mathrm{~cm})$ were also of lead (Fig. 1). The animals were placed with their necks in a gap in the central part of the segments and the irradiated area of the head was approximately delimited by the plane passing through the inferior edge of the occipital bone, i. e. the junction between the cervical vertebrae and the cranium (Fig. 2). Fig. 3 is instructive for the assessment of the extent of the irradiated area; it shows animals from the period in which the loss of pigmentation takes place in the irradiated hair. The focal distance of the gamma ray source from the centre of the head was $76 \mathrm{~cm}$. The dose rate measured with a Victoreen dosimeter was $1.2-1.3 \mathrm{~Gy} / \mathrm{min}$. The residual exposure at the dose rate used was $4 \%$ of the exposure outside the shield in the neck locality (in the centre of the fixation opening), $1 \mathrm{~cm}$ beyond the opening it was $2.5 \%$, and in the centre of the segment $1.1 \%$. The animals were irradiated under pentobarbital anesthesia (Pentobarbital Spofa), achieved by means of the i. p. injection

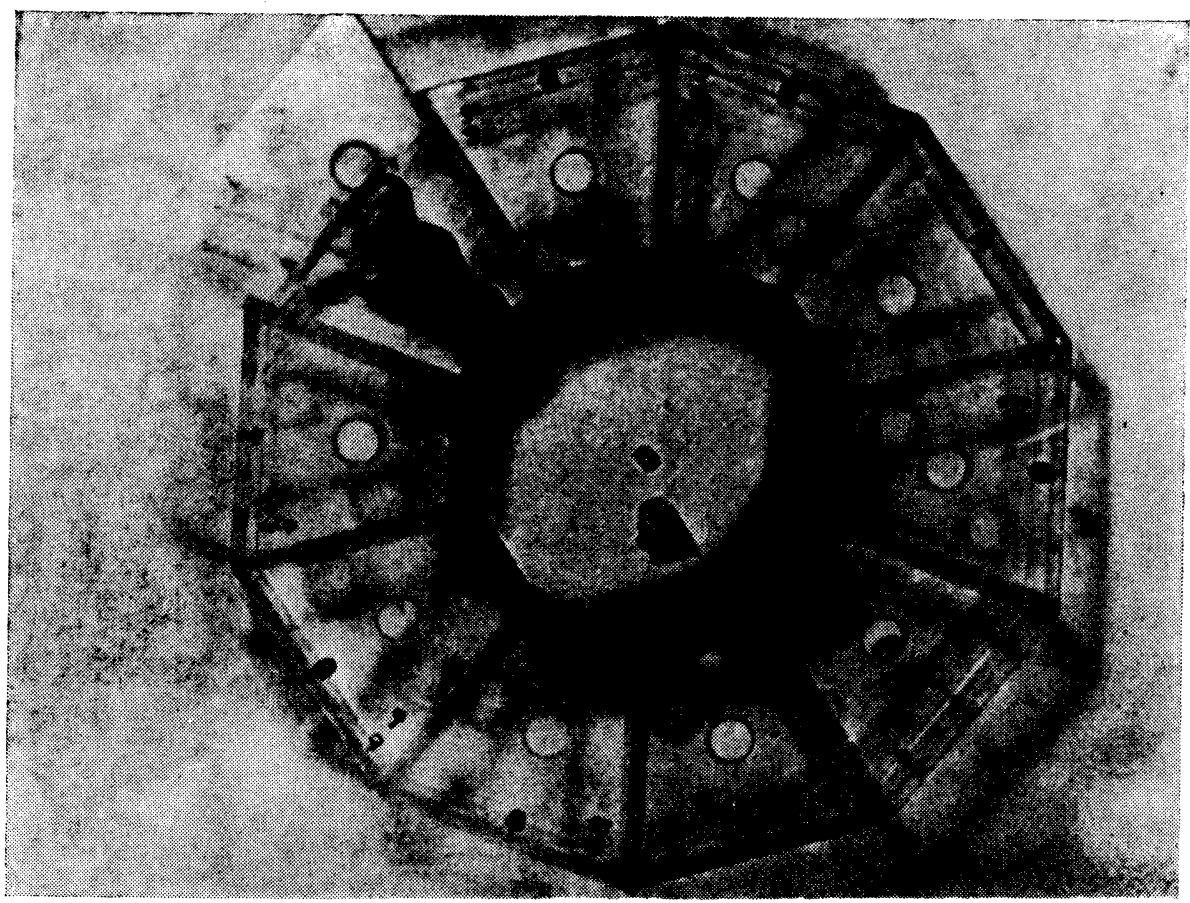

Fig. 2

Position of an anesthetized animal in one of the ten irradiation segments (viewed from above).

of $75 \mathrm{mg}$ substance per $\mathrm{kg}$ body weight approximately $10 \mathrm{~min}$ prior to placing the animals in the fixation chamber and starting irradiation. Control (sham irradiated) animals were also injected with pentobarbital and the mice were fixed in the chamber for the appropriate period without irradiation. In all experiments a dose of $16 \mathrm{~Gy}$ was used, producing $20 \%$ lethality up to the 30th day after irradiation under our experimental conditions (Pospíšil et al. 1985). Mortality of animals was recorded at one-day intervals, body weight determined at weekly and monthly intervals.

\section{Peripheral Blood Cells}

Blood samples were obtained by means of a fine incision in the tail vein. Erythrocyte and leukocyte counts (per $\mu$ l blood) were made using a Coulter Counter, model ZF (Coulter Electronics, Ltd., England). Granulocyte and lymphocyte counts were made by differentiation of smears. The dynamic development of changes in blood cell counts was studied using repeated blood withdrawals from the same individuals, at 14-day intervals. 

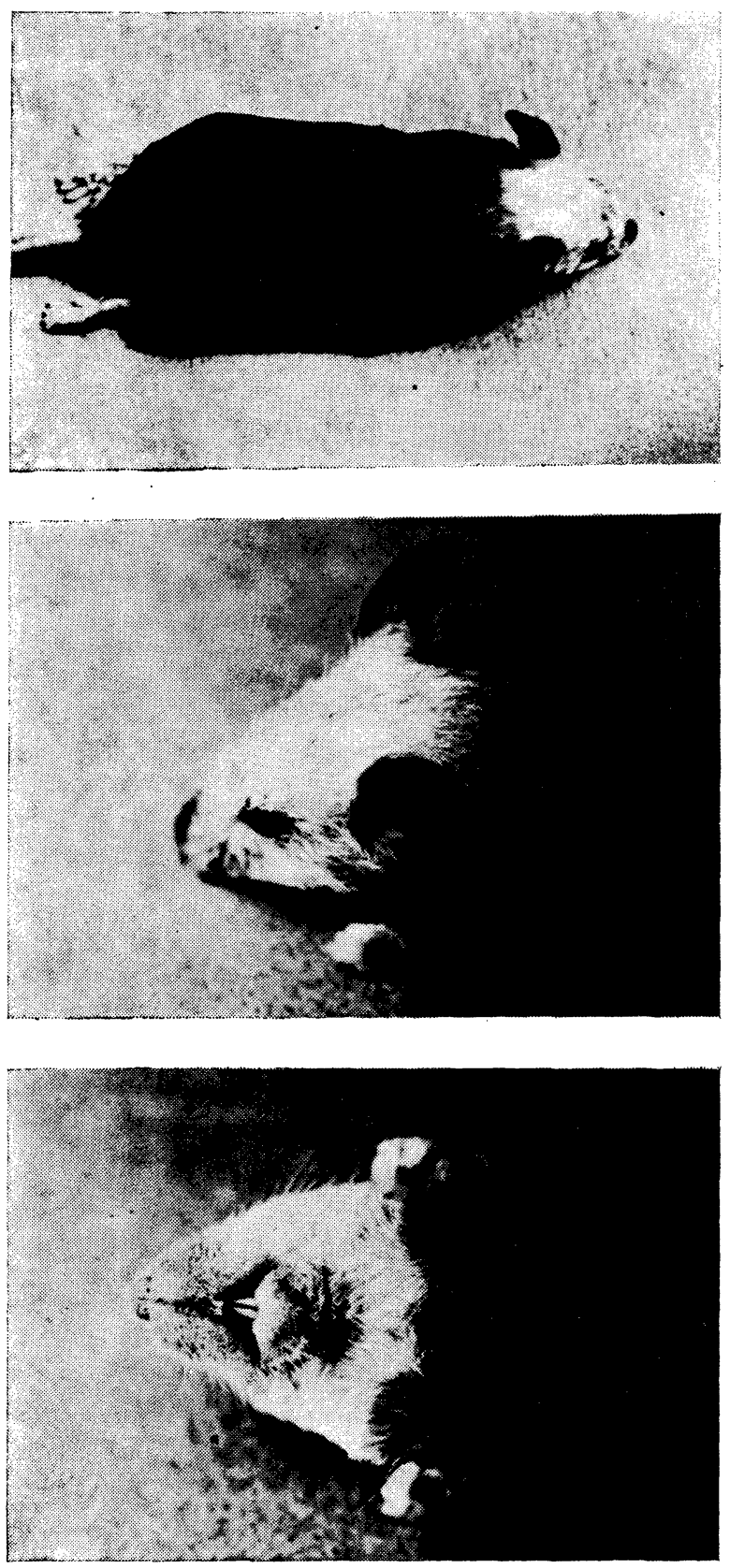

Fig. 3

Bleached hair demonstrates graphically the demarcation line between the irradiated and the shielded areas. 
Volume of Circulating Red Blood Cells

Was determined by the method using the dilution of ${ }^{59} \mathrm{Fe}$ labelled erythrocytes (Vácha 1975) on the 28th day post irradiation. The labelled red blood cells were obtained from donors injected i. p. with $18.5 \times 10^{4} \mathrm{~Bq}{ }^{59} \mathrm{Fe}$ citrate (Rotop, G. D. R.) four days previously and injected i. v. into the experimental animals. After 15 min blood was withdrawn and its radioactivity measured. Hematocrit was determined by the standard semi-micromethod.

\section{Determining of ${ }^{59} \mathrm{Fe}$ Incorporated Into Heme of Erythropoietic Organs}

The method of heme iron (labelled with ${ }^{59} \mathrm{Fe}$ ) extraction from the hemopoietic organs was used as an indicator of the intensity of erythropoiesis in irradiated and control animals. ${ }^{59} \mathrm{Fe}$-citrate diluted with saline was administered to the animals by intraperitoneal injection between 0630 and $0730 \mathrm{hrs}\left({ }^{59} \mathrm{Fe}\right.$-citrate $\mathrm{mfr}$. Rotop, G. D. R., each mouse received $7.4 \times 10^{4} \mathrm{~Bq}$ and $0.37-$ $-0.56 \mu \mathrm{g}$ of elementary iron) on the $14 \mathrm{th}, 27 \mathrm{th}, 42 \mathrm{nd}, 55$ th and 69 th days post irradiation. Six hours afterwards the animals were killed by spinal fracture, the spleen was cleaned and weighed. The skeletons were freed of soft tissues exploiting the necrophage activity of the beetle Dermestes vulpinus Fbr., kept in a laboratory colony as described by Grulich (1977). The samples (spleen, individual bones or their groups) were then mechanically homogenized in liquid nitrogen and subjected to double extraction by means of a mixture of ethyl acetate and acetic acid (3:1), followed by rinsing of the extract with hydrochloric acid in order to remove inorganic iron. The amount of extraction mixture was $2 \times 3.5 \mathrm{ml}$ for the spleen or a bone the size of the femur (details of the method see Vácha et al. 1978). The measurement of radioactivity was performed on a Nuclear Chicago gamma well spectrometer, range $0.5-1.4 \mathrm{MeV}$, efficiency $19 \%$. From each extraction sample $2 \times 1 \mathrm{ml}$ was used. The radioactivity measured was converted to $\%$ of the radioactivity administered and to the radioactivity of the whole bone group or the spleen. Values measured in irradiated animals were then converted to $\%$ of control values $( \pm$ S. E.) and represented in Figs. $5-15$ as full circles.

\section{Correction for Erythrocyte Content in Hemopoietic Tissues}

The method of heme iron extraction removes the interfering influence of storage and other non-heme iron fractions in erythropoietic organs. It includes, however, heme iron of erythrocytes circulating in the vessels of these organs. If the radioactivity of an unit volume of peripheral blood erythrocytes $6 \mathrm{hrs}$ after ${ }^{59} \mathrm{Fe}$ administration is known (it is equal to $1.48 \%$ of the administered radioactivity per $100 \mu \mathrm{l}$ of erythrocytes, Vácha et al. 1982b) and if the volume quantities of peripheral blood erythrocytes in the individual bones and the spleen are also known (Vácha et al. 1980), the corresponding correction could be done. Changes of total erythropoietic activity during the postirradiation period were taken into account when calculating this correction, too. While the "absolute" values of the intensity of erythropoiesis (heme radioactivity in $\%$ of the radioactivity administered) were somewhat lowered by this correction (by $6 \%$ on average), the relative values (irradiated animals in \% of controls) remained effectively unchanged. Only bones with feeble erythropoiesis (acral bones, the skull) witnessed some difference after this correction, see Figs. (corrected values are depicted with empty circles).

Statistical methods

Student's t-test and the non-parametric test of rank order were used (Roth et al. 1962). The values given in Figures are the means \pm S. E. $M$.

\section{Results}

\section{Changes In Body Weight}

of the irradiated mice in $\%$ of controls are depicted as asterisks in Fig. 4. Two mice died in the irradiated group - on the 13th and 14th days. Body weight of irradiated animals declines up to the 14 th day after irradiation, then a partial recovery is evident, but control values are not regained during the experiment.

The control animals exhibit a smooth growth. The differences in body weight between irradiated and control animals are statistically significant at all intervals except the 36 th day. 


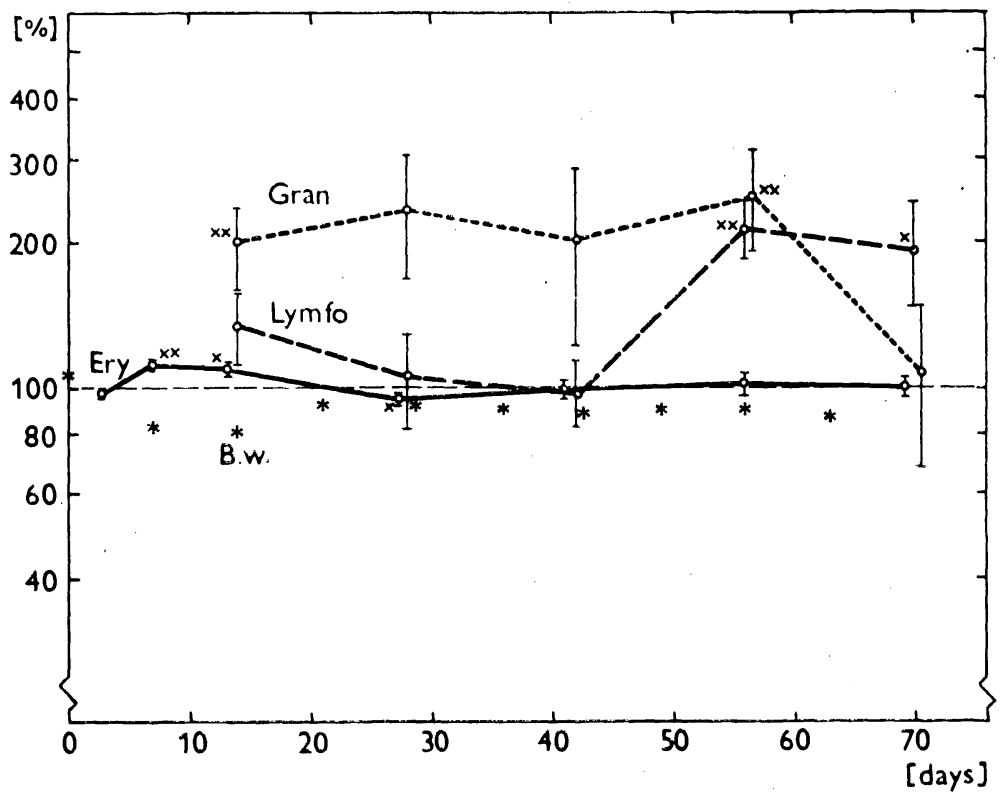

Fig. 4

Peripheral blood cell counts in head-irradiated animals and their body-weight (in $\%$ of controls) plotted against time. Full line - erythrocytes, dashed line - lymphocytes, dotted line - granulocytes, asterisks - body weight. Arithmetical means \pm S. E. are given. Statistical significance of differences: $\mathrm{x}-\mathrm{P}<0.05, \mathrm{xx}-\mathrm{PP}<0.01$.

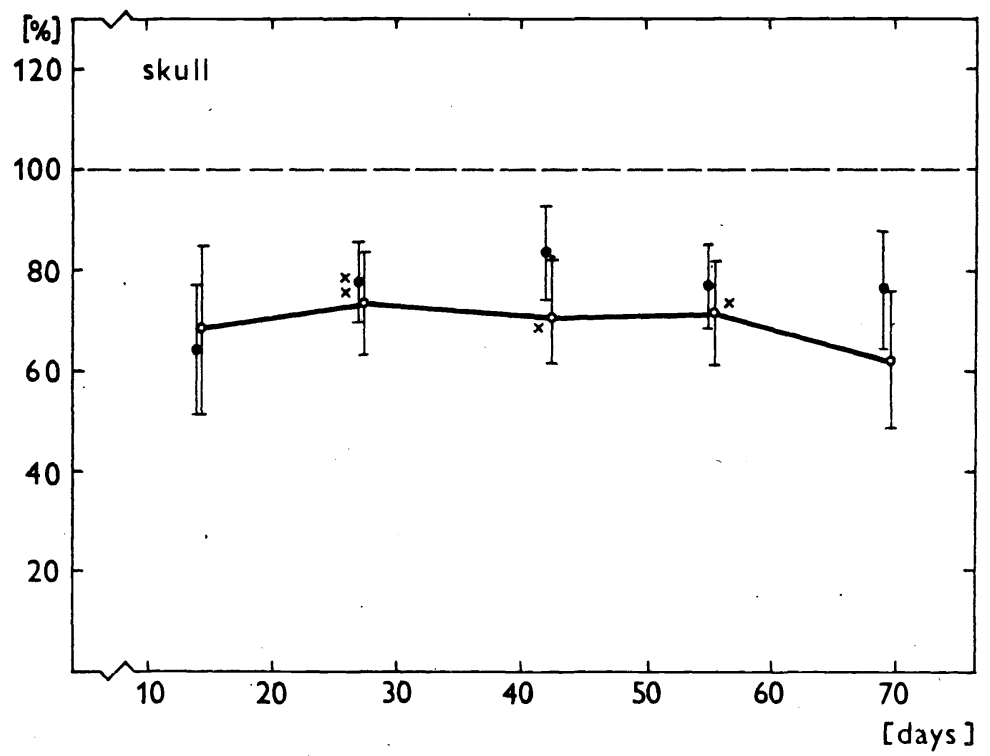

Fig. 5

Intensity of erythropoiesis ( ${ }^{59} \mathrm{Fe}$ incorporation into heme) in the skull irradiated with $16 \mathrm{~Gy}$ (in \% of controls) during the postirradiation period. Empty circles - the radioactivity of circulating erythrocytes deducted, full circles - uncorrected values. Means \pm S. E. are given. Statistical significance of differences: $\mathrm{x}-\overrightarrow{\mathrm{P}}<0.05, \mathrm{xx}-\mathrm{P}<0.01$. 


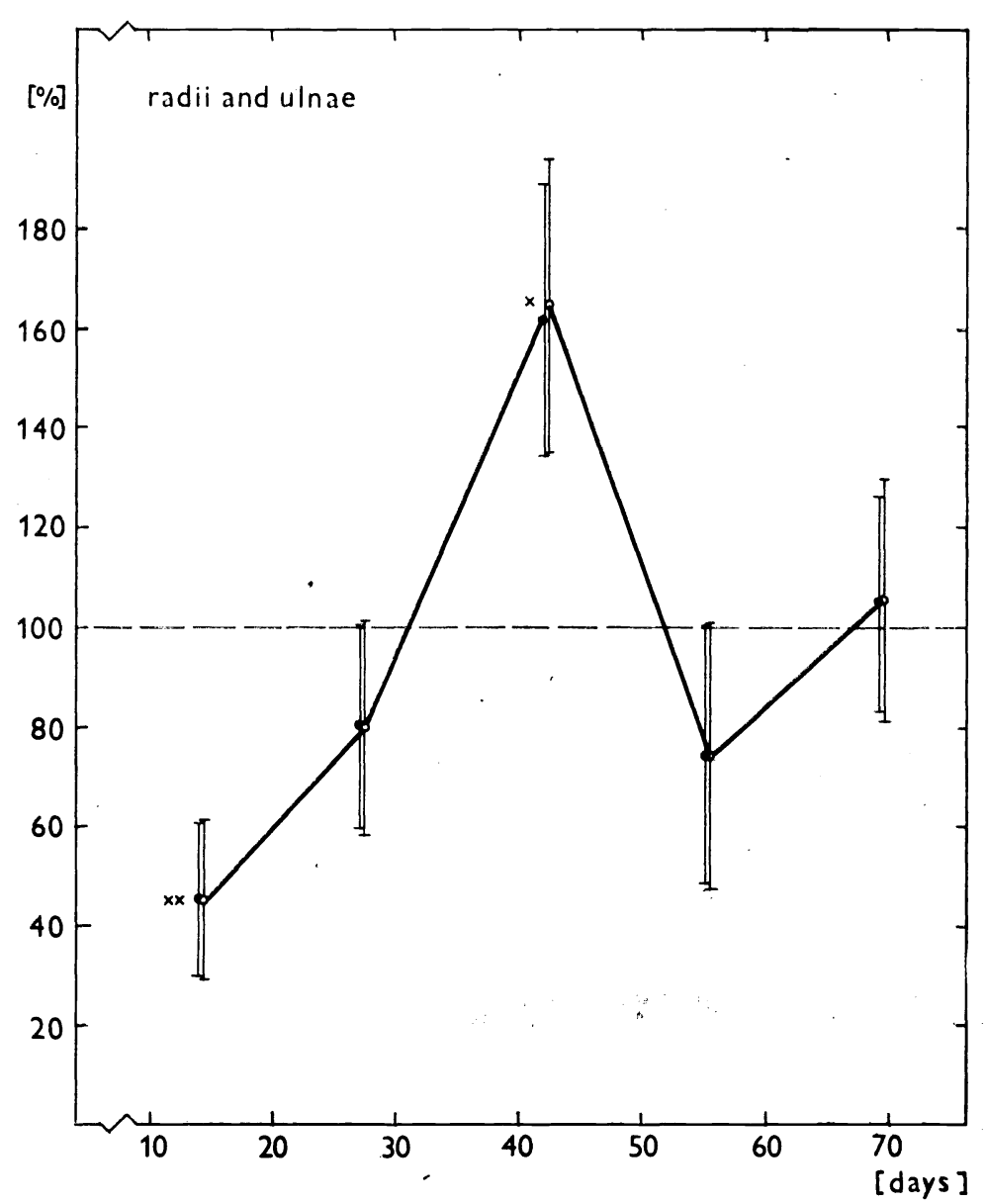

Fig. 6

Intensity of erythropoiesis ( ${ }^{59} \mathrm{Fe}$ incorporation into heme) in the shielded radii and ulnae (in \% of controls) in mice head-irradiated with 16 Gy on day 0 . Other notes as in Fig. 2.

Erythrocytes, Lymphocytes and Granulocytes in Peripheral Blood

The numbers of these components per unit volume of blood are given as a percentage of control values in Fig. 4. The concentration of red blood cells is significantly enhanced on the 7th and 14th days post irradiation; a significant decline is marked on the 28th day, then the concentration stabilizes at control values. The concentration of lymphocytes is significantly enhanced towards the end of our experimental period, $i$. e. on the 56th and 70th days post irradiation. The influence of local head irradiation manifests itself most profoundly in the peripheral granulocyte concentration, which is maintained in the irradiated group on a higher level and significantly exceeds control values at most time intervals. 


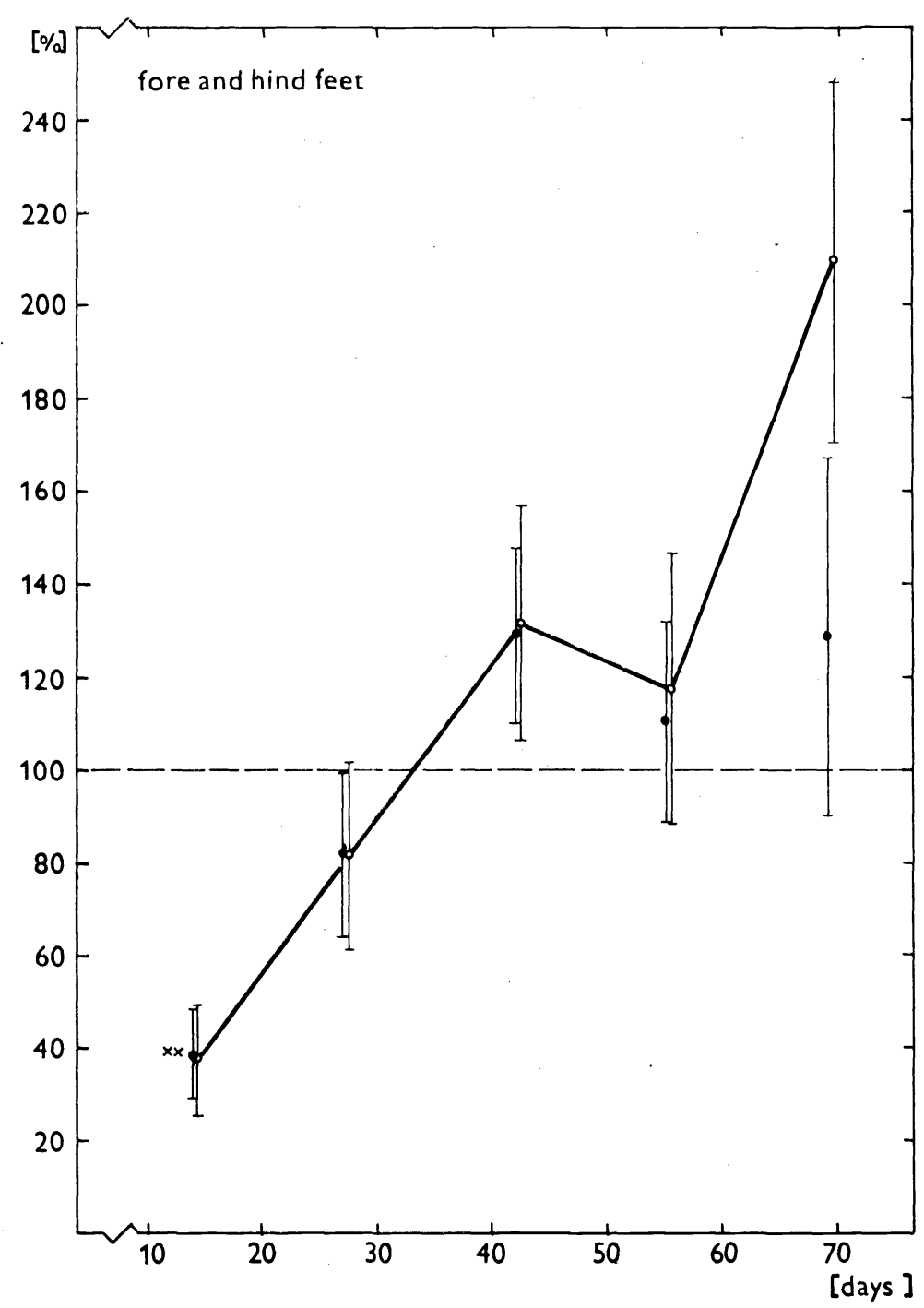

Fig. 7

Intensity of erythropoiesis $\left({ }^{59} \mathrm{Fe}\right.$ incorporation into heme) in the shielded fore and hind feet (in $\%$ of controls) in mice head-irradiated with $16 \mathrm{~Gy}$ on day 0 . Other notes as im Fig. 2.

Volume of Circulating Erythrocyte Mass

on the 28th day post irradiation was $0.75 \pm 0.03 \mathrm{ml}$ in irradiated and $.0 .87 \pm 0.04 \mathrm{ml}$ in control animals; it thus declined to $82.2 \pm 5.2 \%$ of the initial value $(P<0.05)$. 
Intensity of Erythropoiesis in Individual Bone Groups and in the Spleen

The results of the measuring of ${ }^{59} \mathrm{Fe}$ incorporation into the heme in individual bones, bone groups and the spleen are depicted in Figs. 5-14. The values ascertained in irradiated animals are presented as a percentage of values found in control (sham irradiated) animals representing $100 \%$. Abscissa denotes days after irradiation, the values corrected for the erythrocyte content are depicted as empty circles, non-corrected values as full circles. Five to ten animals were used in each group. Statistical significance of the differences in comparison with controls is denoted in Figs.: $\mathrm{x}-$ $\mathrm{P}<0.05, \mathrm{xx}-\mathrm{P}<0.01$.

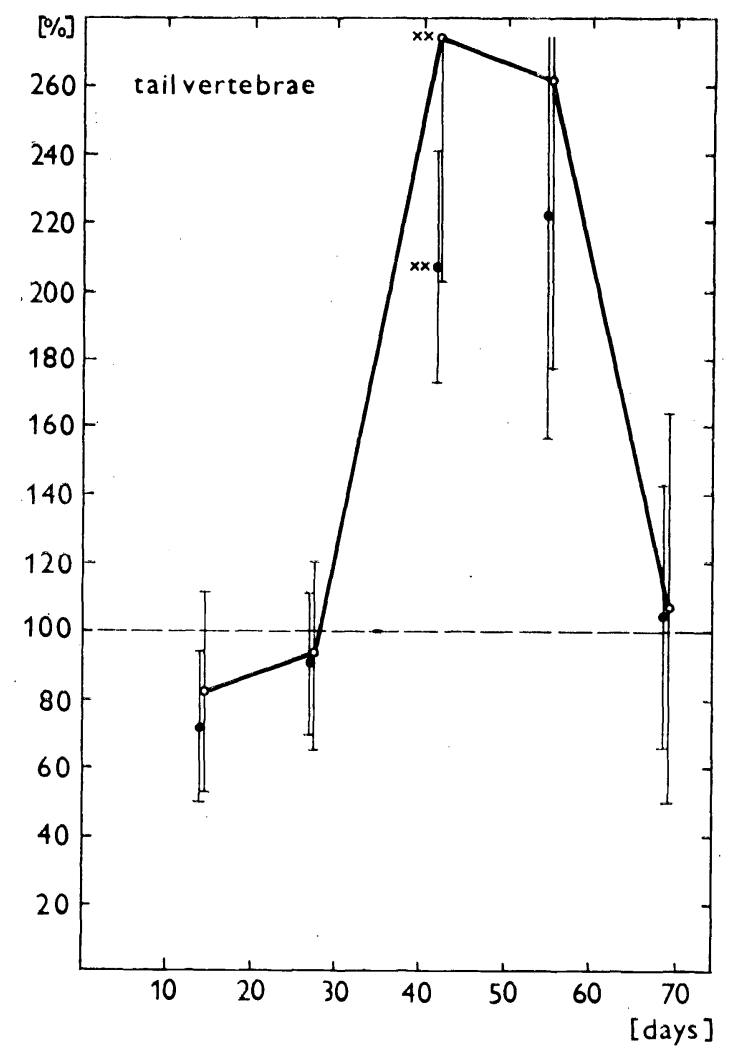

Fig. 8

Intensity of erythropoiesis $\left({ }^{59} \mathrm{Fe}\right.$ incorporation into heme) in the shielded tail vertebrae (in $\%$ of controls) in mice head-irradiated with $16 \mathrm{~Gy}$ on day 0 . Other notes as in Fig. 2. 


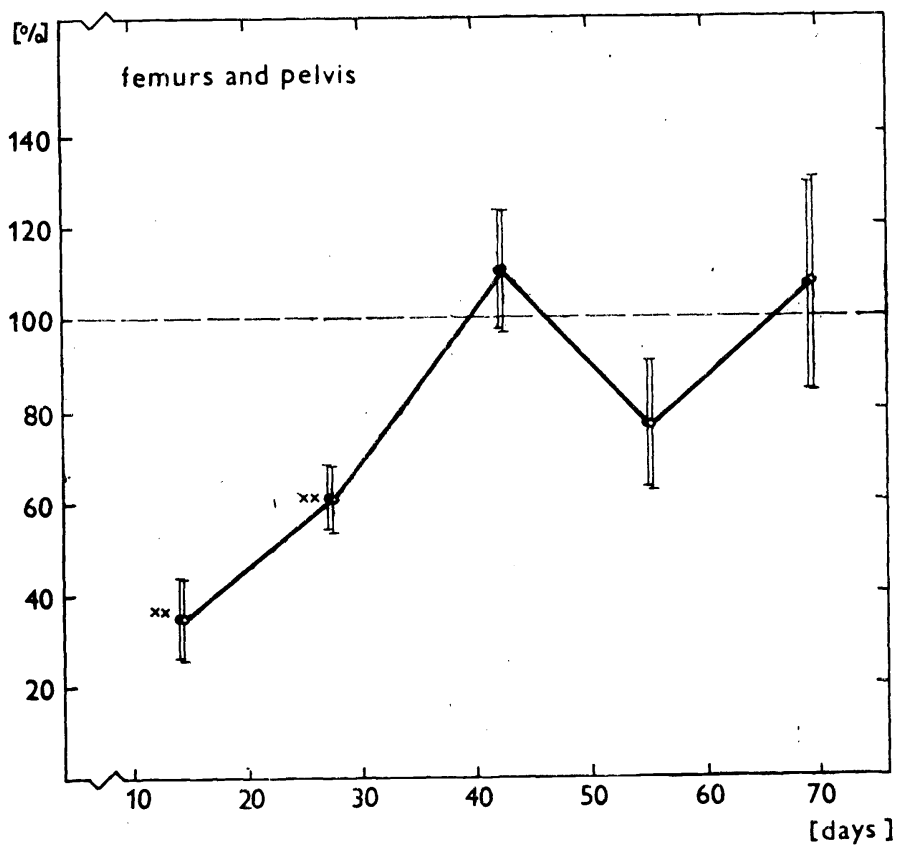

Fig. 9 Intensity of erythropoiesis ( ${ }^{59} \mathrm{Fe}$ incorporation into heme) in pelvis and femurs (in \% of controls) in mice head-irradiated with $16 \mathrm{~Gy}$ day 0 . Other notes as in Fig. 2.

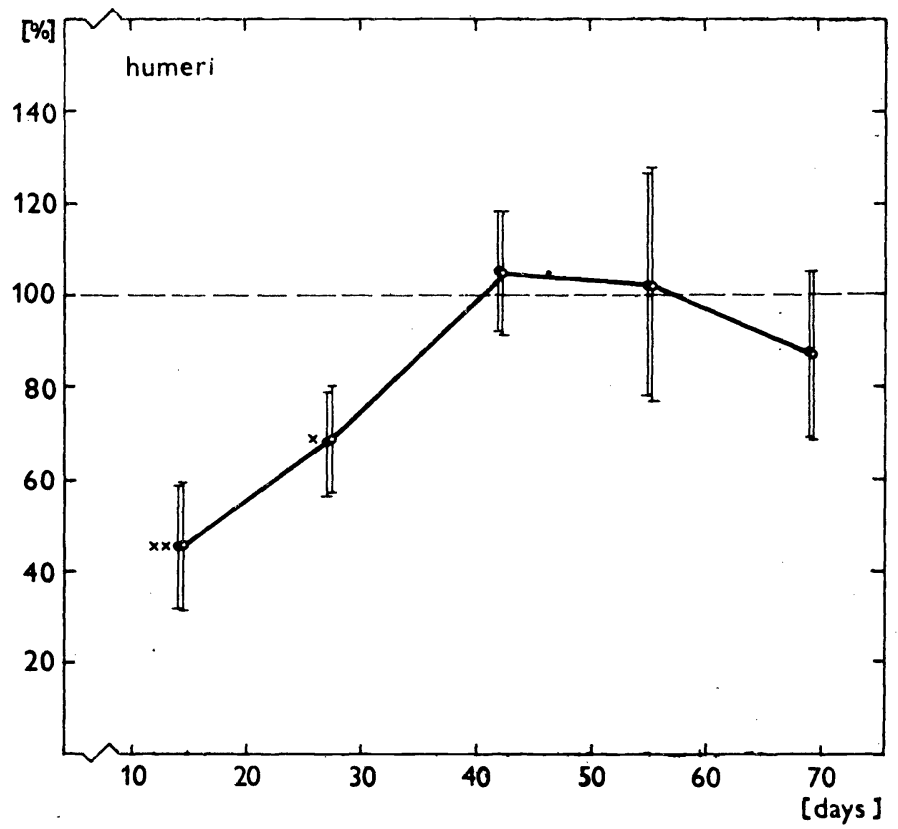

Fig. 10 Intensity of erythropoiesis ${ }^{59} \mathrm{Fe}$ incorporation into heme) in humeri (in \% of controls) in mice head-irradiated with $16 \mathrm{~Gy}$ on day 0. Other notes as in Fig. 2. 


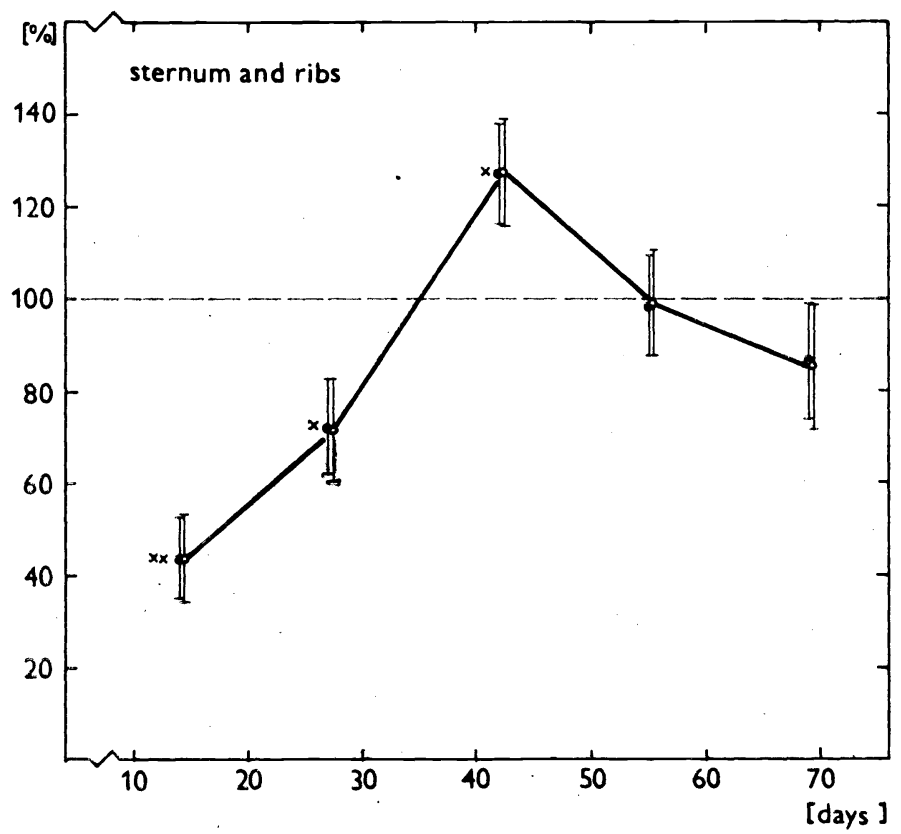

Fig. 11 Intensity of erythropoiesis ( ${ }^{59} \mathrm{Fe}$ incorporation into heme) in sternum and ribs (in \% of controls) in mice head-irradiated with $16 \mathrm{~Gy}$ on day 0. Other notes as in Fig. 2.

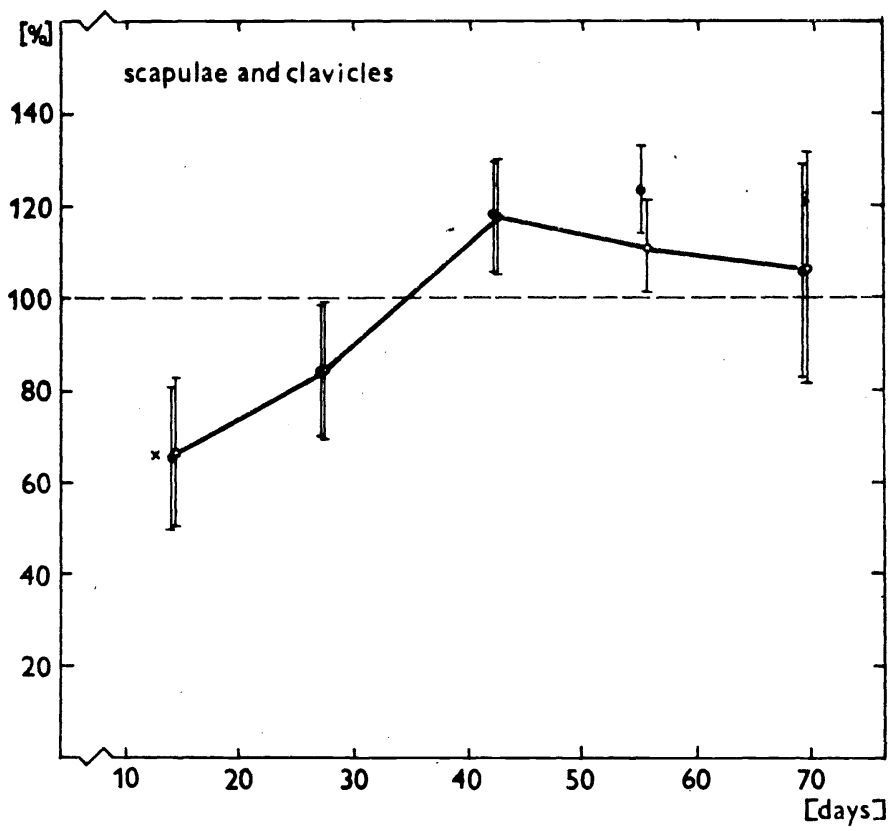

Fig. 12 Intensity of erythropoiesis $\left({ }^{59} \mathrm{Fe}\right.$ incorporation into heme) in scapulae and clavicles (in \% of controls) in mice head-irradiated with $16 \mathrm{~Gy}$ on day 0 . Other notes as in Fig. 2. 
Intensity of erythropoiesis in the skull (including the mandible, Fig. 5) remains steadily on the level corresponding roughly to $70 \%$ of control values between the 14th and 69th days post irradiation. The description of the dynamics of non-irradiated bones could best be done in groups formed after the type of ferrokinetics taking place in them (Vácha et al. 1984). Acral regions (radii and ulnae, fore and hind feet, tail vertebrae, Figs. 6-8) show a more or less marked overshoot of the erythropoiesis above the control values after the initial depression on the 14th day. In contrast to this, the strongly erythropoietic bones (humeri, pelvis and femurs, tibiae and fibulae, spine without tail) do not show a marked overshoot above the control values after the initial decline. Only some of these bone groups are depicted: the spine without tail behaves nearly identically to the pelvis and femurs - Fig. 9, while tibiae and fibulae are indistinguishable from the humeri - Fig. 10. The heme iron incorporation more or less regularly rises from the value of about $40 \%$ on the 14 th day post irradiation towards the control value, which is reached on about the 40th day. The thoracic bones (sternum and ribs, scapulae and clavicles, Figs. 11 and 12) occupy a sort of middle position between both groups mentioned above, with a mild overshoot above the control values on the 42nd day after irradiation. The dynamics of the erythropoiesis in the skeleton as a whole after head irradiation are shown in Fig. 13. Only the decline on the 14th and 28 th days post irradiation is statistically significant, the control value is attained $o$ the 42nd day and held afterwards.

The most pronounced and earliest recovery overshoot is to be seen in the spleen (Fig. 14, full line), reaching more than double control values. Changes in the weight of the spleen run qualitatively roughly parallel to its erythropoietic activity (Fig. 14, dashed line). Owing to the high recovery activity of the spleen, the total erythropoiesis

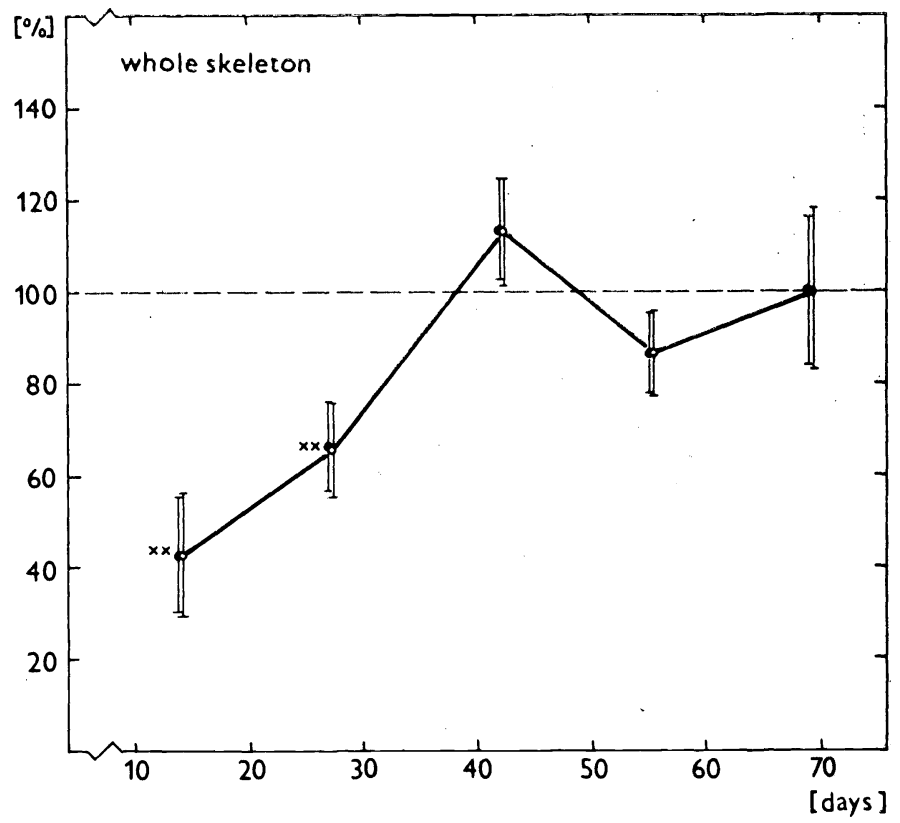

Fig. 13

Intensity of erythropoiesis ( ${ }^{59} \mathrm{Fe}$ incorporation into heme) in the whole skeleton (in \% of controls) in mice head-irradiated with $16 \mathrm{~Gy}$ on day 0 . Other notes as in Fig. 2. 
(in the whole marrow and in the spleen, Fig. 15) recovers more swiftly and overshoots more conspicuously than in the bone marrow alone (Fig. 13). Let us note that the spleen represents in the mice strain used in the rest state a relatively very small erythropoietic component, namely about $9 \pm 1 \%$ of the total erythropoiesis (Vácha et al. 1982a).

A significant depression of erythropoiesis thus takes place after local irradiation of the head. Not only the "direct" damage of the exposed marrow of the skull and the mandible participate in this depression, but also a depression of erythropoiesis in the shielded, non-irradiated regions of the skeleton. In contradistinction to the "persisent" type of depression in the irradiated bones of the head, the depression of the total erythropoiesis is of a transient type and is abolished owing to a recovery effort, which is variably expressed in individual regions of the bone marrow and of the extramedullary erythropoiesis.

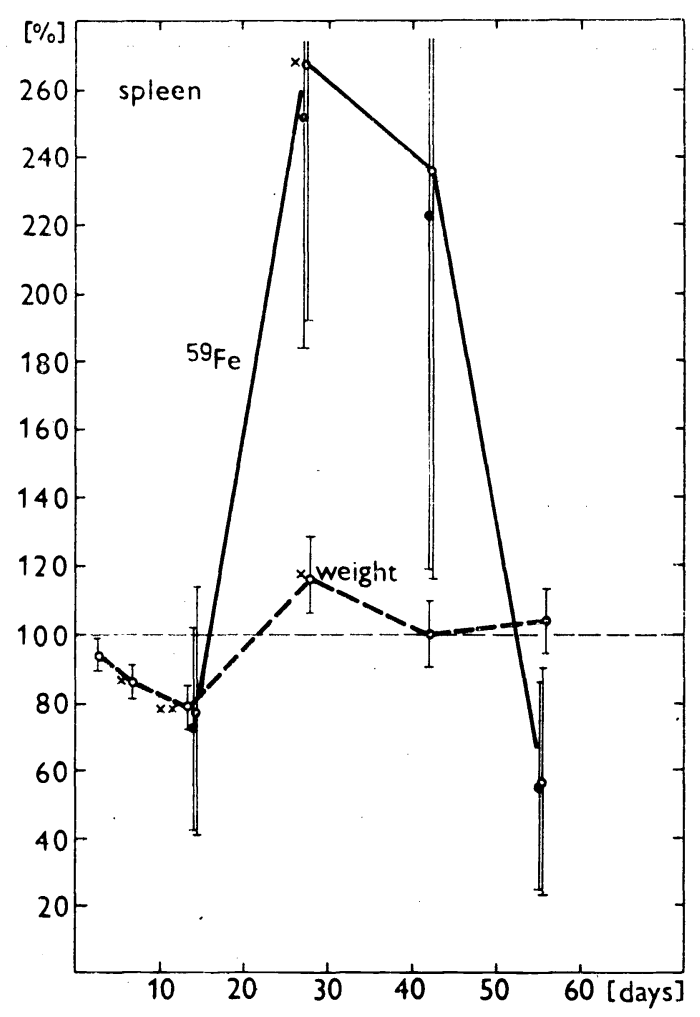

Fig. 14

Intensity of erythropoiesis ${ }^{59} \mathrm{Fe}$ incorporation into heme) in the spleen (in \% of controls) in mice head-irradiated with 16 Gy on day 0 (full line); weight of the spleen - dashed line. Other notes as in Fig. 2. 


\section{Discussion}

The intensity of erythropoiesis in the irradiated region of the haemopoietic system (i. e., in the skull) is steadily lowered to about $70 \%$ of the initial value during the period monitored from the 14th to the 69th days. In view of the fact that the skull represents only $6.71 \pm 0.59 \%$ of the total marrow erythropoiesis in the mouse strain used in the rest state (Vácha et al. 1982a), this decline cannot represent an important anemizing factor. The degree of depopulation of the erythropoietic tissue can be estimated at $5 \times 10^{-8}$ after a dose of $16 \mathrm{~Gy}$ in the irradiated tissue (at $\mathrm{D}_{0}$ of the stem cell =

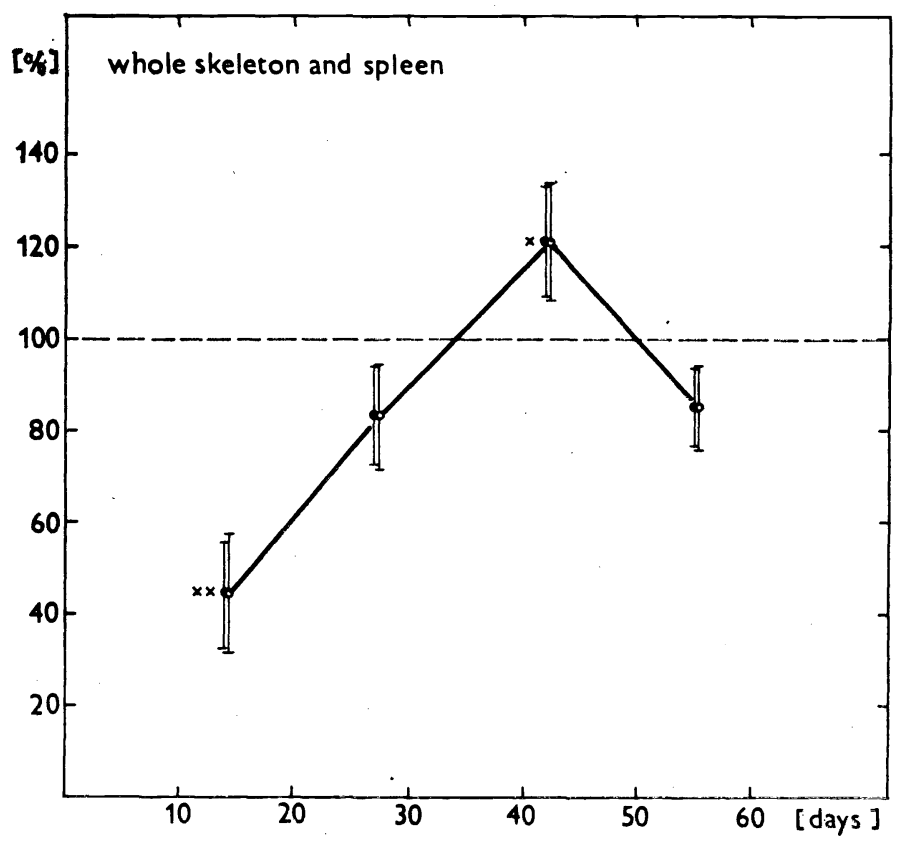

Fig. 15

Intensity of erythropoiesis ( ${ }^{59} \mathrm{Fe}$ incorporation into heme) in the whole erythropoietic system (in \% of controls) in mice head-irradiated with $16 \mathrm{~Gy}$ on day 0 . Other notes as in Fig. 2.

$\left.=0.95 \mathrm{~Gy}, \mathrm{y}=\mathrm{y}_{0} \exp (16 / 0.95)=\mathrm{y}_{0} .5 \times 10^{-8}\right)$. It can be deduced from this that the relatively high degree of erythropoiesis in the skull in the period mentioned is caused by a migration of erythropoietic stem cells from the shielded regions into the skull. That the erythropoiesis does not recover completely even by the 69th day post irradiation, could conceivably be related to the marked destruction of the microenvironment of the bones of the head.

The dominant finding was the transient depression of erythropoiesis in the shielded regions of the hemopoietic system, manifested in the 14th and the 30th days after irradiation of the head. There is no need to explain this observation by other mechanisms than by the known effect of starvation and dehydration originating as a result of irradiation of the head region. The papers cited in the Introduction showed that decreased consumption of food and liquids depresses production of erythropoietin and secondarily also erythropoiesis. This explanation is consistent with both the changes 
found in body weight of the irradiated animals and the dynamics of the periphera erythrocytes. The decline of the body weight on about the 10th day after head irradiation is probably a result of the onset of ulcerative changes in the oral cavity (Goepp and Fitch 1962). Also the timing of the deaths on the 13th and 14th days post irradiation testifies to the prominent role of the oral syndrome. On the other hand, the recovery of body weight from the 21 st day after irradiation probably derives from the renewal of food intake and water consumption after the regeneration of the epithelium of the oral cavity (Goepp and Fitch 1963). The rise in total erythropoiesis (Fig. 15) takes place parallelly with body weight recovery and verifies the close connection between the dynamics of erythropoiesis and the nutritional state of the organism.

The rise in the concentration of erythrocytes in the peripheral blood above the control values on the 7th and 14th days after irradiation is evidently a result of dehydration of the organism and the subsequent hemoconcentration. The decline in this parameter on the 28th day post irradiation could be understood as a result of recovery of the equilibrium of body fluids (i. e., of the cessation of hemoconcentration after overcoming the results of the oral syndrome) and as a result of delayed manifestation of the supression of the marrow production. This is confirmed by the decline of the mass of circulating erythrocytes in this period.

The participation of the individual marrow regions in the repair of erythropoiesis under the conditions of our experiments does not appear to be incidental. In an earlier paper (Vácha et al. 1984) we categorized bones according to the ferrokinetic parameters into a group with a high heme production per unit weight (humeri, pelvis, femurs, tibiae, fibulae, spine without tail), an intermediate group (sternum, ribs, scapulae) and a group with a very low erythropoiesis per unit weight (acral bones, skull). In the present experiments it is the bones with a low physiological level of erythropoiesis which manifest the most conspicuous recovery overshoot above the control level on the 42nd day post irradiation and later. It is probable that these bones are sites of ectopic erythropoiesis under conditions of enhanced demands for its recovery. An extreme case of ectopic erythropoiesis is the spleen, of course, the cellular production of which is not limited by an a priori determined tissue volume as in the case of the bone marrow and the hemopoiesis of which is directed towards erythropoiesis, in contradistinction to the marrow.

Another possible mechanism of anemization of the animals whose head was irradiated is the competition of erythropoiesis with leukopoiesis for the common stem cell. A markedly enhanced level of granulocytes (and also of lymphocytes in the later period) testifies to this possibility (Fig. 4). The granulocyte reaction itself could be a result of an infection process within oral syndrome, but the influence of damage to higher control centres is not excluded. Fedorov et al. (1980) observed inhibition of erythropoiesis and stimulation of granulopoiesis after destructive interference with the hypothalamic region.

In is worth mentioning that long-term observation of our head-irradiated animals showed stunting of growth and in the period six months after irradiation the occurrence of a renewed decline in body weight, wasting and late mortality, not accompanied by a disturbance of the function of marrow hemopoiesis (Pospišil et al. 1984).

\section{Účinek akutního ozáření hlavy myší gama paprsky na erytropoesu v rưzných částech hemopoetického systému}

V celém sledovaném intervalu $14-69$ dní po ozáření hlavy myší dávkou 16 Gy gama paprsky ze zdroje ${ }^{60} \mathrm{Co}$ byl pozorován pokles inkorporace ${ }^{59} \mathrm{Fe}$ do hemové frakce 
kostní dřeně lebky zhruba na $70 \%$ fysiologických hodnot. U stíněných (neozářených) kostních lokalit došlo 14. den po ozáření k poklesu tohoto ukazatele zhruba na $40 \%$, pak však následovala reparace dosahující výchozích hodnot mezi 30. a 40. dnem po ozáření. Zatímco hloubka postiradiačního poklesu je ve všech stíněných oblastech zhruba stejná, vykazují akrální kosti (na rozdíl od dlouhých kostí končetin) ve fázi úzdravy výrazný překmit nad kontrolní hodnoty, tj. náznak ektopické erytropoesy. Hlavním místem ektopické erytropoesy však zůstává slezina. Dočasný pokles erytropoesy ve stíněných oblastech, doprovázený anemisací zvířete, je pravděpodobně dủsledkem zhoršených nutričních podmínek $\mathrm{v}$ rámci tzv. „orálního postiradiačního syndromu«; pokles je po úpravě nutričních poměrů kompensován vlnou regenerace s aktivací ektopických lokalit erytropoesy.

\section{Действие острого облучения головы мышей гамма-лучами на эритропоэз в различных участках гематопоэтической системы}

В течении целого периода наблюдений в интервале от 14 до 69 дня после облучения головы мышей дозой 16 Гр гамма-лучей от источника ${ }^{60} \mathrm{Co}$ наблюдалось снижение инкорпорации ${ }^{59} \mathrm{Fe}$ в гемовую фракцию костного мозга черепа приблизительно на $70 \%$ физиологических величин. У экранированных (необлученных) участках скелета на 14 день после облучения наступило снижение этого показателя приблизительно на $40 \%$, потом следовало восстановление, достигающее исходных величин между 30 и 40 днем после облучения. В то время как глубина постиррадиационного снижения во всех экранированных областях была приблизительно одинаковой, у акральных костей (в отличие от длинных костей конечностей) наблюдался в фазе выздоровления выразительный выброс над уровень контрольных величин, т. е. намечивание эктопического эритропоэза. Основным местом эктопического эритропоэза остается все же селезенка. Временное снижение эритропоэза в экранированных областях, сопровождаемое анемизацией животного, является по всей вероятности следствием ухудшенных условий снабжения в рамках т. н. «орального постиррадиационного синдрома»; снижение после восстановления снабжения компенсируется 'волной регенерации с активированием эктопоэтических участков эритропоэза.

\section{References}

ARCHAMBEAU, J. O. - STRYCKMANNS, P. - BRENNEIS, H.: The effect of food and water deprivation on the peripheral blood parameters of the mouse. Radiat. Res., 36, 1968: $396-409$.

CARO, J. - SILVER, R. - ERSLEV, A. J. - MILLER, O. P. - BIRGEGARD, G.: Erythropoietin production in fasted rats. J. Lab. Clin. Med., 98, 1981: 860-868.

DUNN, C. D. R.: Effect of dehydration on erythropoiesis in mice: relevance to the "anemia" of space flight. Aviat. Space Environ. Med., 49, 1978: 990-993.

FEDOROV, N. A. - LICHOVECKAJA, Z. M. - LVOVIČ, A. I.: Gemopoez u krys s rozrušennymi jadrami zadnego otdela gipotalamusa po pokazateljam absoljutnego čisla kletok kostnogo mozga. Bjul. Eks. Biol. Med., 89, 1980: 349-351.

GOEPP, R. - FITCH, F.: Pathological study of oral radiation death in mice. Radiat. Res., 16, 1962: $833-845$.

GOEPP, R. - FITCH, F.: Prevention of death in mice after lethal irradiation of the head. Radiat. Res., 19, 1963: 670-675. 
GRULICH, I.: Osteologische Präparation mit der Verwendung der kadaverikolen Käfer (Dermestes vulpinus Fbr., Coleoptera, Insecta). Lynx (Prague) n. s., 19/1977, 1977: 87-98.

KILBRIDGE, T. M. - FRIED, W. - HELLER, P.: The mechanism by which plethora supresses erythropoiesis. Blood, 33, 1969: 104-113.

KRANTZ, S. B. - JACOBSON, L. O.: Erythropoietin and the regulation of erythropoiesis. The University of Chicago Press, Chicago and London, 1970, p. 18.

POSPÍSIL, M. - NETÍKOVÁ, J. - KOZUBÍK, A. - PIPALOVÁ, I. - TKAḊLEČEK, L. VIKLICKÁ, S.: Late effects of total-head gamma irradiation in mice. I. Observations on mortality, body weight changes and bone-marrow hemopoiesis. Radiobiologia - Radiotherapia, 26, 1985: 469-476.

QUASTLER, M. - AUSTIN, M. K. - MILLER, M.: Oral radiation death. Radiat. Res., 5, 1956: $338-353$.

ROTH, Z. - JOSÍFKO, M. - MALÝ, V. - TRČKA, V.: Statistické metody v experimentální medicíně. Státní zdravotnické nakladatelství, Praha, 1962.

VÁCHA, J. - DUNGEL, J. - KLEINWÄCHTER, V.: Determination of heme and non-heme iron content of mouse erythropoietic organs. Exp. Hematol., 6, 1978: 718-724.

VÁCHA, J. - HOLÁ, J. - DUNGEL, J. - ZNOJIL, V.: The volume of plasma and erythrocytes in individual bones and in the spleen of mice under physiological conditions and with acute radiation-induced atrophy of the haemopoietic tissue. Acta Haemat., 64, 1980: 165-171.

VÁCHA, J. - HOLÁ, J. - DUNGEL, J, - ZNOJIL. V.: The distribution of erythropoiesis over the various anatomical regions of the erythropoietic system in some inbred strains of mice. Exp. Hematol., 10, 1982a: 768-773.

VÁCHA, J. - ZNOJIL, V. - HOLÁ, J. - DUNGEL, J.: The internal iron kinetics in mice. Acta Vet. Brno, 51, 1982b: 3-22.

VÁCHA, J. - ZNOJIL, V. - HOLÁ, J. - DUNGEL, J.: Iron kinetics in individual bone marrow regions (bones) in mice. Acta Vet. Brno, 53, 1984: 119-136.

WERTS, E. D. - JOHNSON, M. J. - DeGOWIN, R. L.: Postirradiation hemopoietic repopulation and stromal cell viability. Radiat. Res., 71, 1977: 214-224.

WERTS, E. D. - JOHNSON, M. J. - DeGOWIN, R. L.: Abscopal suppression of bone marrow erythropoiesis, Radiat. Res., 76, 1978: 206-218.

YOSHII, Y. - MAKI, Y. - TSUNOMOTO, H. - KOIKE, S. - KASUGA, T.: The effect of acute total-head $\mathrm{X}$ irradiation on $\mathrm{C}_{3} \mathrm{H} / \mathrm{He}$ mice. Radiat. Res., 86, 1981: 152-170. 